\title{
TOXICOLOGICAL AND MICROBIOLOGICAL ESTIMATION LEVEL OF POLLUTION ECOSYSTEMS IN THE INDUSTRIAL REGION OF UKRAINE - KRIVOY ROG CITY
}

DOI: 10.36740/WLek202009212

\author{
Luibov V. Hryhorenko, Svitlana Yu. Yehorova \\ DNIPROPETROVSK MEDICAL ACADEMY MINISTRY OF HEALTH OF UKRAINE, DNIPRO, UKRAINE
}

\begin{abstract}
The aim: Scientific substantiation necessary of PMWW application for the ecologically safe formation of the secondary ecosystems in the mining and iron ore processing areas. Materials and methods: Sanitary-chemical investigation of water samples ( $\mathrm{n}=132)$; biological objects - plants and aquatic biota was conducted on the content of $\mathrm{Pb}, \mathrm{Cd}, \mathrm{Zn}$, $\mathrm{Mn}, \mathrm{Cu}, \mathrm{Cr}, \mathrm{Ni}$, Fe ( $\mathrm{n}=112)$; wild plants samples ( $\mathrm{n}=135)$; sanitary-microbiological and parasitological indicators $1-3$ years old waste water sludge (WWS) ( $\mathrm{n}=68)$. Results: Overnormal concentrations of salt had been found in water samples, taken from the river Inhulets (2.1 MPL), sulfates and carbonates (2.7 MPL), iron (2.1 MPL), chloride (1.7 MPL), magnesium (3.1 MPL). In wells from nearest villages water is not suitable for drinking purposes and contains total sum of salts $-4.97 \mathrm{MPL}$, sulfates and carbonates - 5.16 MPL, cadmium - 3.7 MPL, lead - 1.53 MPL. Thus, the toxic heavy metals concentrations ( $\mathrm{Pb}, \mathrm{Cd}, \mathrm{Zn}, \mathrm{Mn}, \mathrm{Cu}, \mathrm{Cr}, \mathrm{Ni}, \mathrm{Fe})$ in the fish and amphibians did not exceed the permissible levels.

Conclusions: Total pollution of the soil within six months after application of sludge correspond to the "permissible" level $\left(Z_{c}=1.61\right)$. Use of clearing facilities sludge aged from 1.5 years old and of longer in the amount $15 \mathrm{~kg} / \mathrm{m}^{2}$ did not lead to increased concentration of heavy metals in the top layer of dumps.
\end{abstract}

KEY WORDS: mining area, wastewater treatment, sludges, pollution, contaminants, heavy metals, chemical and epidemiological safety

Wiad Lek. 2020;73(9 p. II):1962-1967

\section{INTRODUCTION}

Mining at the Eastern regions of Ukraine is accompanied by significant environmental shifts; there impact on the natural landscape could be compared to the historical geological processes in a geosphere [1]. In the area of mining and processing enterprises of Krivoy Rog (MPEK) - North, South, Inhulets and Central mining enterprises to the external dumps of quarries was carried out over 3700 ha of usable area and brought about 1000 ha of the nearest landfills [2]. Technogenic geosystems (quarries, dumps) are often contiguous with settlements in the city, but were not suitable for any use: their surface is dead, biodiversity is minimal, microclimatic conditions are far from natural. Majority of artificial landscapes formed as the result of waste storage mining, being the source of potential risk to the human health [3]. For natural transformation of these territories, and reproduction of biodiversity, mostly constrained by an acute shortage of nutrients in the dead soil, should necessary 30 - 50 years, while anthropogenic landscape will adversely affect on the located areas [4-6]. Artificial acceleration natural processes of rehabilitation of man-made landscapes due to the exogenous supply of organic matter provides the opportunity to reduce their environmental risks and return recreational use of the large areas near the cities. Perspective should become usage of the waste utilities - precipitation of the municipal wastewater (PMWW), which is based on a safe and economical disposal method. PMWW contain a significant amount (50-70\%) of plant nutrients - humphry organic substances, but last time they did not used in the agriculture due to the heavy metal compounds [7] and sources of the infectious and viral diseases [8]. Every year on the sewage treatment facilities in major of industrial cities of Ukraine produced about 1 million $\mathrm{m}^{3}$ of precipitation. Majority of these treatment facilities (about 2 thousand) is situated in Dnipropetrovsk region - $18 \%$, more than other regions of Ukraine [9]. Waste water sludge (WWS) is a constant source of the soil, surface and underground waters, atmospheric air contamination with hydrogen sulfide, ammonia, gaseous products of putrefaction of proteins. Further expansion of sludge areas due to the increase of lands is impossible, therefore, disposal of sludge for the numerous cities in Ukraine is an urgent ecological and hygienic problem [10].

\section{THE AIM}

Scientific substantiation necessary of PMWW application for the ecologically safe formation of the secondary ecosystems in the mining and iron ore processing areas.

\section{MATERIALS AND METHODS}

It was research non recultivated waste dumps in Krivoy Rog mining and processing enterprises (MPE) as the dangerous objects, which adversely affect to the all bordering territories. We carried out water samples, taken from river 
Inhulets in two experimental districts. District № 1 was located on the distance 1 kilometer from the overburden dump, which corresponds to the industrial zone. District № 2 was situated on the distance 3 kilometers from the overburden dump, which corresponds to the settlements zone.

Sanitary-chemical investigation of water samples included the following laboratory research: dry residue, total hardness, iron, chloride, sulphate, magnesium, ammonium, calcium, nitrites and nitrates, $\mathrm{pH}$ of water $(\mathrm{n}=132)$. Sanitary-chemical research of the sediments from artificial reservoirs near the settlements Chervone, Kalinino, Chabanovo, Zaporozhets in Dnipropetrovsk region was carried out $(n=123)$. Research of biological objects - plants and aquatic biota was conducted on the limited number of indicators - content of some heavy metals $(\mathrm{Pb}, \mathrm{Cd}, \mathrm{Zn}$, $\mathrm{Mn}, \mathrm{Cu}, \mathrm{Cr}, \mathrm{Ni}, \mathrm{Fe})(\mathrm{n}=112)$. Research of wild plants samples, taken from the residential areas and areas bordering with artificial ponds, was carried out to the contents of heavy metals ( $\mathrm{Pb}, \mathrm{Cd}, \mathrm{Zn}, \mathrm{Mn}, \mathrm{Cu}, \mathrm{Cr}, \mathrm{Ni}, \mathrm{Fe})(\mathrm{n}=135)$. Sanitary-microbiological and parasitological indicators of $1-3$ years old waste water sludge (WWS), having been taken from aeration stations in Krivoy Rog city $(n=68)$. Concentrations of the total, mobile, water soluble forms of the given heavy metals (HV) in the $1-3$ years old WWS, taking from aeration stations in Krivoy Rog city, have been studied $(n=78)$.

In our research we used local maximum permissible levels of HM in the fish and plant food products, because in Ukraine MPL depends on a background level of chemical pollution in the mining and iron ore processing areas. According to the Ukrainian hygienic standards [11], there is common MPL for different types of sanitary zones: the industrial zone, settlements zone, recreational zone. Therefore, we carried out our experiment in the territory of two sanitary zones. District № 1 was placed on the territory of industrial zone. District № 2 was situated on the territory of settlements zone. We determined the average annual indicators of water quality in the surface water supply source - Karachunovskyi reservoir, which is located in the industrial urbanization zone. The Kryvorozhska zone of urbanization covers city Kryvyi Rih, territory of Karachunovskyi reservoir with SPZ areas; rural areas of Dnipropetrovsk region. The class of water supply source for each of the indicators was determined by ISO 4008: 2007 [12], and water quality from the Karachunovskyi reservoir was analyzed according to Sanitary Rules and Norms № 4630-88 [13]. Among indicators of water quality from Karachunovskyi reservoir were the following: organoleptic - smell, taste and aftertaste, turbidity; total hardness, dry residue, sulphates, chlorides, permanganate oxidation, $\mathrm{pH}$, bichromatic oxidation, soluble oxygen, total organic carbon, chemical content: $\mathrm{Mo}, \mathrm{As}, \mathrm{Ni}, \mathrm{Zn}, \mathrm{Na}-\mathrm{K}, \mathrm{Ca}, \mathrm{Mg}$, $\mathrm{Fe}, \mathrm{Mn}, \mathrm{Cu}, \mathrm{F}$, cyanides, calcium phosphate, ammonia nitrogen, nitrite, nitrates, silicic acid, synthetic surfactants, polyphosphates, petroleum products. Totally 33 indicators of water quality were studied. The majority of water quality indicators from Karachunovskyi reservoir were carried out during (2008-2016) years, salt composition of water (content of total hardness, dry residue, sulfates, manganese) was studied.

\section{RESULTS}

In the water samples, taken from river Inhulets from the control sites below location of overburden dump, overnormal concentrations of chemical compounds were observed. In the experimental district № 1 we received the following results of laboratory research: dry residue (2.6 maximum permissible level - MPL), total hardness (2.9 MPL), iron (1.8 MPL), chloride (2.3 MPL), sulphate (1.4 MPL), magnesium (3.5 MPL), ammonium (1.1 MPL). In the experimental district № 2 had been shown overnormal concentrations of dry residue (up to $2.1 \mathrm{MPL}$ ), total hardness (up to 2.7 MPL), iron (up to 2.1 MPL), chloride (up to 1.7 MPL), sulphate (up to 1.4 MPL), magnesium (3.1 MPL). Concentrations of the calcium, nitrites and nitrates were below hygienic standards. According to the data of laboratory research, $\mathrm{pH}$ of water in the both experimental districts was varied $(7.4-7.9)$, which corresponds to the hygienic requirements.

Sanitary-chemical research sediments from artificial reservoirs near the settlements Chervone, Kalinino, Chabanovo, Zaporozhets indicated about absence of their anthropogenic chemical contamination by HM. Concentrations of the total and mobile forms of HM in the whole soil samples did not exceed MPL. Sanitary-chemical research of water quality in the stagnant surface waters, having been taken from all rural settlements, included to our scientific work, carried out its compliance with sanitary-hygienic norms. In the local water ponds water samples had excessive total content of inorganic salts $(2601.66 \pm 602.00) \mathrm{mg} / \mathrm{dm}^{3}(2.6$ MPL) and high total hardness $(25.16 \pm 8.40) \mathrm{mg} / \mathrm{dm}^{3}$ (3.59 MPL), overnormal concentrations of lead (1.0-2.5 MPL) and cadmium (1.3-7.5 MPL). Results of analyses of wells water located in the rural settlements indicated about its complete unsuitability for drinking purposes. Water from local wells does not correspond to the hygienic requirements: high content of salts (up to $4.97 \mathrm{MPL}$ ), total hardness (up to $5.16 \mathrm{MPL}$ ), and high turbidity (3.58 MPL). Amount of inorganic salts in some wells was on the level $(4971.6 \pm 0.07) \mathrm{mg} / \mathrm{dm}^{3}$, general rigidity $(36.16 \pm 0.29)$ $\mathrm{mg} / \mathrm{dm}^{3}$. It was determined high concentrations of toxic metals, such as cadmium (up to 3.7 MPL) and lead (up to $1.53 \mathrm{MPL}$ ).

Research of biological objects - plants and aquatic biota was conducted on the limited number of indicators content of some $\mathrm{HM}(\mathrm{Pb}, \mathrm{Cd}, \mathrm{Zn}, \mathrm{Mn}, \mathrm{Cu}, \mathrm{Cr}, \mathrm{Ni}, \mathrm{Fe})$. At the research of aquatic biota - in the fish and amphibians (frogs) biomass was shown, that the concentration of HM $(\mathrm{Pb}, \mathrm{Cd}, \mathrm{Zn}, \mathrm{Cu}, \mathrm{Cr}, \mathrm{Ni}, \mathrm{Fe}$ ) did not exceed the maximum permissible levels (MPL) for fish products, except content of manganese (table I).

In all samples of fish and amphibians biomass was determined the highest concentrations of manganese and iron, in comparison with other HM. Content total forms of manganese $(0.82 \pm 0.40) \mathrm{mg} / \mathrm{kg}$ exceeded MPL for fish 
Table I. Content of heavy metals in the fish and amphibians tissues, taken from stagnant surface water objects near the settlements, located to overburden dump career of Inhulets mining enterprises $(n=112)$

\begin{tabular}{|c|c|c|c|c|c|c|c|c|}
\hline \multirow{2}{*}{ Form of heavy metals } & \multicolumn{8}{|c|}{ Concentration, $\mathrm{mg} / \mathrm{kg}\left(\mathrm{M} \pm \mathrm{m}, \mathrm{X}_{0,25}-\mathrm{X}_{0,75}\right)^{*}$} \\
\hline & $\mathrm{Pb}$ & Cd & $\mathrm{Zn}$ & $\mathrm{Mn}$ & $\mathrm{Cu}$ & $\mathrm{Cr}$ & $\mathrm{Ni}$ & $\mathrm{Fe}$ \\
\hline Total & $\begin{array}{c}0.46 \pm \\
0.11 \\
(0.25- \\
0.69)\end{array}$ & $\begin{array}{c}0.033 \pm \\
0.008 \\
(0.016-0 . \\
052)\end{array}$ & $\begin{array}{c}1.45 \pm \\
0.38 \\
(0.66-2.43)\end{array}$ & $\begin{array}{c}0.82 \pm \\
0.40 \\
(0.19-1.04)\end{array}$ & $\begin{array}{c}1.03 \pm \\
0.41 \\
(0.27-1.43)\end{array}$ & $\begin{array}{c}0.49 \pm \\
0.13 \\
(0.24-0.70)\end{array}$ & $\begin{array}{c}0.26 \pm \\
0.06 \\
(0.21-0.35)\end{array}$ & $\begin{array}{c}3.86 \pm \\
2.13 \\
(0.56-8.26)\end{array}$ \\
\hline $\begin{array}{c}\text { Maximum } \\
\text { permissible level** }^{*}\end{array}$ & 1.0 & 0.2 & 40.0 & 0.76 & 10.0 & - & - & 5.0 \\
\hline
\end{tabular}

Note: * $-(\mathrm{X} 0,25-\mathrm{X} 0,75)$ - interquartile scope $(25-75 \%){ }^{* *}-\mathrm{MPL}$ - maximum permissible levels of heavy metals in the fish products.

Table II. Content of heavy metals in the wild plants, taken from stagnant surface water objects near the settlements, located to overburden dump career of Inhulets mining enterprises $(n=135)$

\begin{tabular}{cccccccccc}
\hline \multirow{2}{*}{ Form of heavy metals } & \multicolumn{7}{c}{ Concentration, $\mathrm{mg} / \mathrm{kg}\left(\mathrm{M} \pm \mathrm{m}, \mathrm{X}_{0,25}-\mathrm{X}_{0,75}\right)^{*}$} \\
\cline { 2 - 9 } & $\mathrm{Pb}$ & $\mathrm{Cd}$ & $\mathrm{Zn}$ & $\mathrm{Mn}$ & $\mathrm{Cu}$ & $\mathrm{Cr}$ & $\mathrm{Ni}$ & \\
\hline \multirow{3}{*}{ Total } & $0.21 \pm$ & $0.047 \pm$ & & & & & \\
& 0.06 & 0.007 & $<4.0$ & $<50.0$ & $<2.0$ & $<0.5$ & $<4.0$ & 0.72 \\
& $(0.11-$ & $(0.03-0.06)$ & & & & & $(8.09-9.91)$ \\
\hline
\end{tabular}

$\begin{array}{cccccc}\begin{array}{c}\text { Maximum } \\ \text { permissible level }^{* *}\end{array} & 0.5 & 0.1 & 50.0 & - & 10.0\end{array}$

Note: ${ }^{*}-\left(X_{0,25}-X_{0,75}\right)$ - interquartile scope $(25-75 \%) ; *$ - MPL - maximum permissible levels of heavy metals in the food products of plant origin.

production in 1.08 times. In some fishes and amphibians specimens content of total forms of iron ranged from $(0.56$ to 8.26$) \mathrm{mg} / \mathrm{kg}$, which corresponded to $(0.11-1.65) \mathrm{MPL}$. At the research of wild plants samples, taken from the residential areas and areas bordering with artificial ponds, was found that contents of $\mathrm{HM}(\mathrm{Pb}, \mathrm{Cd}, \mathrm{Zn}, \mathrm{Mn}, \mathrm{Cu}, \mathrm{Cr}$, $\mathrm{Ni}, \mathrm{Fe}$ ) did not exceed MPL for agricultural plants. This indicated about low probability of translocation all these $\mathrm{HM}$ and absence of accumulation $\mathrm{Pb}, \mathrm{Cd}, \mathrm{Zn}, \mathrm{Mn}, \mathrm{Cu}, \mathrm{Cr}$, $\mathrm{Ni}, \mathrm{Fe}$ to the local plants (table II).

By epidemic indicators WWS, keeping in the sludge ponds about 1 year old, were relatively dangerous, and did not contain viable pathogenic microorganisms, but had numerous saprophytic microflora (coliforms and anaerobes) and viable eggs of geohelminths. Sanitary-microbiological indicators of 3 years old WWS corresponded to the uncontaminated soil, they should not contain viable eggs of geohelminths. Given WWS was epidemiology safety (table III).

It have been determined, that average content of the total, mobile and water-soluble forms of HM in the 3 years old WWS did not exceed their threshold concentrations, by the water migration indicator of harm (table IV).

Application WWS with different period of accumulation in order to create artificial soil in all experimental landfills carried out to the increasing saprophytic microorganisms, which should be primary factor in formation of the nutrient humic substances. While applying WWS with 1.5 years of exposition in the experimental plots at the concentration $\left(15 \mathrm{~kg} / \mathrm{m}^{2}\right)$ was observed significant increase amount of mesophilic aerobic and facultative anaerobic microorganisms (MAFAM) from 35000 to $309000 \mathrm{CFU}$ in 1 gram of soil. Average content of MAFAM in all experimental plots was on the level $(1.85 \pm 0.29) \cdot 10^{5} \mathrm{CFU}$ in 1 gram of soil $(\mathrm{p}<0.01)$. The same trend was observed in the experimental soils with $\left(30 \mathrm{~kg} / \mathrm{m}^{2}\right)$ of WWS. Quantity of MAFAM colonies also increased from 31400 to 394000 CFU in 1 gram of soil. Average content of MAFAM in all experimental plots was $(2.94 \pm 0.26) \cdot 10^{5} \mathrm{CFU}$ in $1 \mathrm{~g}$ of absolutely dry soil. At the research titre of sanitary-indicative microorganisms have been shown «clean» sanitary condition of soil by coli-titre after 1.5 years and of longer term of WWS exposition. Titre Clostridium perfringens in all experimental samples of artificial soil was ( 0.1 and > 0.1 ), which corresponds to the soil characteristic ("clean"). It was determined, that application 1.5 years old WWS at the amount $\left(15 \mathrm{~kg} / \mathrm{m}^{2}\right)$ in the experimental plots did not carried out to the increasing total forms of HM, or their background concentrations, MPL, and clarks. For copper, the total content $(5.38 \pm 0.29) \mathrm{mg} / \mathrm{kg}$ exceeded its background concentration - coefficient of concentration $\left(\mathrm{C}_{c}=2.94\right)$. Total content of zinc $(20.00 \pm 0.31) \mathrm{mg} / \mathrm{kg}$ exceeded a background concentration $\left(\mathrm{C}_{c}=3.67\right)$. By the total pollution index $\left(\mathrm{Z}_{c}=\right.$ 1.61), HM contamination of soils from career Inhulets after 6 months accumulation of WWS the soil sanitary state characterized as "permissible". It was found that using WWS on the concentration $\left(30 \mathrm{~kg} / \mathrm{m}^{2}\right)$ in the experimental plots carried out to the significant increase content of total forms of HM: manganese $(75.66 \pm 0.28) \mathrm{mg} / \mathrm{kg}$, zinc $(58.94 \pm 0.18)$ $\mathrm{mg} / \mathrm{kg}$ and copper $(28.45 \pm 0.28) \mathrm{mg} / \mathrm{kg}(\mathrm{p}<0.001)$. However, the total pollution index $\left(Z_{c}=12.1\right)$ corresponds to the "acceptable" level of pollution. 
Table III. Sanitary-microbiological and parasitological indicators of $1-3$ years old waste water sludge, having been taken from aeration stations in Krivoy Rog city $(\mathrm{n}=68)$

\begin{tabular}{cccccc}
\hline $\begin{array}{c}\text { Time of } \\
\text { waste water } \\
\text { sludge (WWS) } \\
\text { accumula-tion } \\
\text { in the aeration } \\
\text { stations }\end{array}$ & $\begin{array}{c}\text { Total number } \\
\text { of saprophytic } \\
\text { microorganisms, } \\
\text { colony forming units } \\
\text { (CFU in 1 gram of WWS) }\end{array}$ & $\begin{array}{c}\text { Titer of } \\
\text { anaerobes } \\
\text { (Clostridium } \\
\text { Perfringens) }\end{array}$ & $\begin{array}{c}\text { Number } \\
\text { E. Coli, } \\
\text { (CFU in 1 g } \\
\text { of soil) }\end{array}$ & $\begin{array}{c}\text { Pathogenic } \\
\text { microorganisms all } \\
\text { types }\end{array}$ & $\begin{array}{c}\text { Number of the } \\
\text { geohelminths eggs } \\
\text { (per /100 g) }\end{array}$ \\
\hline 1 year & $1.5 \cdot 10^{7}-2.2 \cdot 10^{7}$ & $0.001-0.0001$ & $890-999$ & should be absent & $3-8^{*}$ \\
\hline 3 years & $6.0 \cdot 10^{3}-1.5 \cdot 10^{4}$ & 0.01 & $<100$ & should be absent & $2^{* *}$ \\
\hline
\end{tabular}

Note: * viable eggs of Fasciola hepatica; ${ }^{* *}$ - non-viable eggs of ascarids (Toxocara canis).

Table IV. Average contents of heavy metals in the 3 years old waste water sludge, having been taken from aeration stations in Krivoy Rog city $(\mathrm{n}=78)$

\begin{tabular}{|c|c|c|c|c|c|c|c|}
\hline \multirow{2}{*}{$\begin{array}{c}\text { Form of heavy } \\
\text { metals (HM) }\end{array}$} & \multicolumn{7}{|c|}{ Concentration of HM (mg/kg, limits of variation/mean)* } \\
\hline & $\mathbf{P b}$ & Cd & $\mathrm{Zn}$ & Mn & $\mathrm{Cu}$ & $\mathrm{Cr}$ & $\mathrm{Ni}$ \\
\hline \multirow{2}{*}{ Total } & $1.2-106.0$ & $\underline{0.1-4.6}$ & $18.0-259.2$ & $60.0-232.0$ & $24.0-165.0$ & 8.0-33.4 & $2.0-73.1$ \\
\hline & 20.0 & 0.2 & 198.1 & 182.3 & 48.9 & 17.6 & 23.5 \\
\hline \multirow{2}{*}{ Mobile } & \multirow{2}{*}{$<0.1$} & \multirow{2}{*}{$<0.1$} & $55.1-132.7$ & $34.0-90.3$ & $\underline{3.2-57.4}$ & \multirow{2}{*}{$<0.1$} & $\underline{0.1-8.9}$ \\
\hline & & & 77.6 & 55.4 & 12.9 & & 2.6 \\
\hline \multirow{2}{*}{ Water soluble } & \multirow{2}{*}{$<0.1$} & \multirow{2}{*}{$<0.1$} & $30.8-45.9$ & $10.4-58.7$ & $\underline{0.8-17.4}$ & \multirow{2}{*}{$<0.1$} & \multirow{2}{*}{$<0.1$} \\
\hline & & & 36.6 & 39.6 & 4.1 & & \\
\hline $\mathrm{MPL}_{\text {total' }^{\prime}}(\mathrm{mg} / \mathrm{kg})$ & $\begin{array}{c}32.0 \\
(260.0)^{*}\end{array}$ & $\begin{array}{c}1.5 \\
(1.5)\end{array}$ & - & $\begin{array}{l}1500.0 \\
(1500)\end{array}$ & - & 80.0 & - \\
\hline $\mathrm{MPL}_{\text {mobile form' }}(\mathrm{mg} / \mathrm{kg})$ & - & - & $\begin{array}{c}23.0 \\
(200.0)\end{array}$ & - & $\begin{array}{c}3.0 \\
(72.0)\end{array}$ & 6.0 & $\begin{array}{c}4.0 \\
(14.0)\end{array}$ \\
\hline $\begin{array}{c}\text { Background soil } \\
(\mathrm{mg} / \mathrm{kg})\end{array}$ & 18.0 & 0.09 & 63.0 & 612.0 & 22.0 & 78.0 & 25.0 \\
\hline
\end{tabular}

Note: * - in the brackets - threshold concentrations of HM in the soil, estimated by water migration indicator of harm.

Table V. Suitability of WWS for landscape reclamation of the anthropogenic contaminated territories

\begin{tabular}{|c|c|c|c|c|c|}
\hline \multirow[b]{2}{*}{$\begin{array}{l}\text { Degree of validity } \\
\text { WWS for landscape } \\
\text { reclamation }\end{array}$} & \multicolumn{4}{|c|}{ Indicators of epidemic safety* } & \multirow[b]{2}{*}{$\begin{array}{l}\text { Concentration of } \\
\text { HM } \\
\text { (exceeds of MPL) }\end{array}$} \\
\hline & $\begin{array}{l}\text { Titre } \\
\text { E. Coli }\end{array}$ & $\begin{array}{c}\text { Titre } \\
\text { Clostridium } \\
\text { Perfringens }\end{array}$ & $\begin{array}{c}\text { Number of } \\
\text { geohelminths eggs (in } \\
1 \mathrm{~kg} \text { of soil, viable) }\end{array}$ & $\begin{array}{c}\text { Pathogenic } \\
\text { microorganisms }\end{array}$ & \\
\hline $\begin{array}{l}\text { Regulated indicators for } \\
\text { «suitable» WWS }\end{array}$ & $\begin{array}{c}0.1-1.0 \\
\text { and more }\end{array}$ & $\begin{array}{c}0.01-0.1 \\
\text { and more }\end{array}$ & $\begin{array}{c}\text { should be } \\
\text { absent }\end{array}$ & should be absent & $1-10$ \\
\hline $\begin{array}{l}\text { Results of our research } \\
\text { for } \\
1.5 \text { years old WWS } \\
\text { accumulation in the soil }\end{array}$ & $\begin{array}{c}0.1- \\
1.0\end{array}$ & $\begin{array}{c}0.01-0.1 \\
>1,0\end{array}$ & $\begin{array}{c}\text { should be } \\
\text { absent, except for single } \\
\text { non-viable eggs of } \\
\text { Toxocara canis }\end{array}$ & $\begin{array}{c}\text { pathogenic } \\
\text { enterobacteria, } \\
\text { Salmonella, } \\
\text { pathogenic } \\
\text { Staphylococcus, } \\
\text { fungi and yeast } \\
\text { should be absent }\end{array}$ & $\begin{array}{c}\mathrm{Pb}, \mathrm{Cd}, \mathrm{Zn}, \mathrm{Ni}, \mathrm{Mn} \\
<\mathrm{MPL} ; \\
\mathrm{Cr}(3.3 \mathrm{MPL}) \\
\mathrm{Cu} \\
(1.45 \mathrm{MPL})\end{array}$ \\
\hline
\end{tabular}

Note: * - Titre of thermofils in the experimental plots, taken from Inhulets mining enterprise career should not determine, because a period of survey for thermophilic microorganisms in WWS corresponds from 2-3 to 5-6 months.

In order to assess suitability of WWS for recultivation surface of waste dumps and waste pits we recommended list of epidemic safety indicators and their chemical composition, which are distributed according to such criteria: "suitable", "conditionally suitable" in combination with natural soils or inert rocks, "not suitable". Comparative assessment suitability of WWS carried out at a wastewater treatment plant in Krivoy Rog for landscape reclamation secondary ecosystems was recommended by the "Criteria of epidemic safety and toxicological hazard of WWS" (table V).
For suitable conditions of the soil formation on a surface of overburden dump with optimal ratio of nitrogen, phosphorus and potassium (N:P:K) we proposed intake of WWS on a working dose ( $300 \mathrm{~kg} / \mathrm{ha}$ by nitrogen amount) with $70 \%$ of humidity and 1.5 year of accumulation in the soil. Based on an average amount of nitrogen in the old WWS (4.5\%), taken from wastewater treatment plant in Krivoy Rog, we recommended maximum amount of WWS (66.7 - 70.0 ton/ha).

In the water from Karachunovskyi reservoir total hardness increasing, according to the levels of average annual indicators: 
from $6.76 \pm 0.40 \mathrm{mg} / \mathrm{dm}^{3}$ in $2008-2016$ years to $10.28 \pm 0.44 \mathrm{mg} /$ $\mathrm{dm}^{3}$ in 2002-2012 years. During 2008-2016 years in summer period, according to the level of total hardness water from the reservoir concerned to the 3rd class of surface water sources, according to ISO 4008:2007 "satisfactory, acceptable water quality". Dry residue for 2008-2016 years did not exceed the established hygienic standard $\left(1000 \mathrm{mg} / \mathrm{m}^{3}\right)$, but water from this reservoir belonged to the 3 rd class, according to the classification of surface water ISO 4008:2007 [12]. The sulphate content of water from this reservoir was classified as 4 class of hazard for the period of observation 2008-2016 years. By to the content of chlorides was observed dynamics of reduction on 1.34 times: from $(139.58 \pm 2.49)$ to $(104.33 \pm 1.80) \mathrm{mg} / \mathrm{dm}^{3}$. Water quality belonged to the 3 rd class $\left(101-250 \mathrm{mg} / \mathrm{dm}^{3}\right)$. According to the level of average index $0.262 \pm 0.013 \mathrm{mgN} /$ $\mathrm{dm}^{3}$, ammonium nitrogen corresponded to the 2nd class of quality $0.10-0.30 \mathrm{mgN} / \mathrm{dm}^{3}$. Nitrite nitrogen did not exceed MPC $\left(3.3 \mathrm{mgN} / \mathrm{dm}^{3}\right)$ for all period of observation. Water belonged to the $3 \mathrm{rd}$ class of quality. It should be noted that nitrate nitrogen content showed a negative trend during 2008-2016 years, but concentrations of these compounds did not exceed MPC (45 mgN/dm $\left.{ }^{3}\right)$.

\section{DISCUSSION}

Results of the study of environmental objects (surface and groundwater, bottom sediments, wild plants, fish and amphibians) in the settlement zone of Dnipropetrovsk region, adjacent to the territory of the worked career, revealed excessive salinization of ponds and mine wells and excess of toxic HM, namely cadmium and lead, which may be a sign of human-made impact on the quality of a long-term waste storage facilities and mine drainage.

Water of mine wells located in the rural settlements (Chervone, Kalinino, Gomelske, Zaporozhets, Chabanovo) is completely unsuitable for drinking purposes due to the excessive content of inorganic salts $(4971.6 \pm 0.07) \mathrm{mg} /$ $\mathrm{dm}^{3}$ and increased total stiffness $(36.16 \pm 0.29) \mathrm{mg} \mathrm{eq} / \mathrm{dm}^{3}$, respectively (4.97 and 5.16) MPC.

It was found that in the body of fish and amphibians (frogs) the content of gross forms of $\mathrm{HM}(\mathrm{Pb}, \mathrm{Cd}, \mathrm{Zn}, \mathrm{Cu}$, $\mathrm{Cr}, \mathrm{Ni}, \mathrm{Fe}$ ) did not exceed MPL for fish products, except manganese $(0.82 \pm 0.40) \mathrm{mg} / \mathrm{kg}$ and iron $(3.86 \pm 2.13)$ $\mathrm{mg} / \mathrm{kg}$, concentrations of which exceeded MPC for fish products: for manganese (up to $1.08 \mathrm{MPC}$ ) and iron (up to 1.65 MPC). It was found that in the plants - wild grasses in the settlements bordering on ponds, content of gross forms of $\mathrm{HM}(\mathrm{Pb}, \mathrm{Cd}, \mathrm{Zn}, \mathrm{Mn}, \mathrm{Cu}, \mathrm{Cr}, \mathrm{Ni}, \mathrm{Fe})$ did not exceed MPL for agricultural plant products, which testified to the low probability of mass transfer of these HM according to the translocation indicator of harmfulness and absence a danger of accumulation of $\mathrm{Pb}, \mathrm{Cd}, \mathrm{Zn}, \mathrm{Mn}, \mathrm{Cu}, \mathrm{Cr}, \mathrm{Ni}, \mathrm{Fe}$ in the phytomass of wild grasses.

An innovative technology of using PMWW for the formation of secondary ecosystems, developed and applied by us in the territory of the former career, has many advantages over traditional methods of application of PMWW. Data from the literature and our own research have shown that the current technologies for the use of PMWW are accompanied by pollution of the environment with chemicals and biological substances.

Thus, at the traditional method of using PMWW as organo-mineral fertilizer, there is a risk of contamination agricultural soils by HM, which transfer to the soil from PMWW and pathogens of infectious diseases and geohelminths. Under such conditions, use of PMWW as organic fertilizers poses a risk of contamination fertile soils by $\mathrm{HM}$ and inclusion of the latter in food chains, and, as a consequence, transfer into the human body.

Our innovative technology for inclusion of organic matter in the natural cycle is achieved by diluting PMWW with inert materials: natural soils or inert overburden rocks of spent careers. Innovative technology of using PMWW is recommended by us for the formation of human-made landscapes of spent careers will avoid environmental problems associated with epidemiological, toxicological and genotoxic safety of the environment, and prevent the migration of exogenous chemicals to the human body through ecological chains.

\section{CONCLUSIONS}

On the basis of Krivoy Rog iron mining ore deposit companies (Ukraine) the complex field studies focused on the fast development of secondary landscapes in the surface of dumps after iron mining were carried out. Overnormal concentrations of salt had been found in water samples, taken from the river Inhulets in a zone of influence breed (2.1 MPL), sulfates and carbonates (2.7 MPL), iron (2.1 MPL), chloride (1.7 MPL), magnesium (3.1 MPL). In the wells from nearest villages water is not suitable for drinking purposes and contains total sum of salts - 4.97 MPL, sulfates and carbonates - 5.16 MPL, cadmium - 3.7 MPL, lead - 1.53 MPL. Thus, the toxic heavy metals concentrations $(\mathrm{Pb}, \mathrm{Cd}, \mathrm{Zn}, \mathrm{Mn}, \mathrm{Cu}, \mathrm{Cr}, \mathrm{Ni}, \mathrm{Fe})$ in the fish and amphibians, as well as herbaceous plants in these areas did not exceed the permissible levels.

Use of clearing facilities sludge aged from 1.5 years old and of longer in the amount $15 \mathrm{~kg} / \mathrm{m}^{2}$ did not lead to increased concentration of heavy metals in the top layer of dumps. Total pollution of the soil within six months after application of sludge correspond to the "permissible" level $\left(Z_{c}=1.61\right)$. It was found that water in Karachunovskyi reservoir is not conditioned by salt composition and belongs to the 3-4 class of water supply sources. It has a high content of total hardness, dry residue, sulfates, chlorides for a long time of observation 2008-2016 years, which is explained by the systematic discharge of highly mineralized mine waters from mining enterprises in the city Kryvyi Rih, pollution of the Ingulets and Saksagan rivers, and subsequent pollution water of the reservoir. Unfavorable tendency to self-cleaning water of the reservoir, by the indicators of nitrifying activity during 2008-2016 years was shown.

\section{REFERENCES}

1. Vernadsky G.0. Podjom nauki [Rise of Science]. Russian Revien. 1969; 28: 1700-1917. (In Russian). 
2. Prokopov V.0., Lipovetskaya O.B.Vplyv mineralnoho skladu pytnoi vody na zdorovia naselennia [Influence of mineral composition of drinking water on the state of health of population]. Hygiene of populated areas. 2015; 59: 63-74. (In Ukrainian).

3. Hryhorenko L.V. Potable water quality in the Karachunyvskyi reservoir. Austrian Journal of Technical and Natural Sciences. 2014; 1: 40-45.

4. Hryhorenko L.V. Water quality assessment in the mining and industrial region on the example of Karachunovskyi reservoir in Ukraine. Advanced Engineering Forum. 2019; 33: 19-31.

5. Hryschenko S.V., Agarkov V.I., Grin N.V. et al. Vplyv khimichnoho skladu pytnoi vody na chastotu zakhvoriuvanosti endokrynnoi systemy sered naselennia ekokryzovoho rehionu Ukrainy [Influence of the chemical composition of drinking water on the frequency of diseases of the endocrine system among population of the ecocrisis region of Ukraine]. Proceedings of XIV Congress of Hygienists in Ukraine "Hygienic science and practice at the turn of the century".2014; 1:301-304. (In Ukrainian).

6. Jill Richardson. What San Francisco Found in Their Own Sludge. La Vida Locavore blog. 2017; 8: 17-20.

7. Tewari A., Chauhan L., Kumar D. et al. Municipal sludge leachate-induced genotoxicity in mice a subacute study. Mutat. Research. 2018;587:9-15.

8. Pandard P., Devillers J., Charissou A. et al. Selecting a battery of bioassays for ecotoxicological characterization of wastes. Scient. Total Environment. 2016; 363 (1-3): 114-125.

9. Stankiewicz V.V., Tarabarova S.B. Hihiienichni aspekty mihratsii promyslovykhstichnykh voduzemlisilskohospodarskoho pryznachennia. Innovatsiini shliakhy vyrishennia problemy enerhozabezpechennia mist, resursiv [Hygienic aspects of industrial wastewater for irrigation of agricultural land. Innovative ways to address urgent problems of basic industries, environment, energy and resources]. Hygiene of settlements. 2017; 3: 167-170. (In Ukrainian).

10. Wang C., Hu X., Chen M. et al. Total concentrations and fractions of $\mathrm{Cd}$, $\mathrm{Cr}, \mathrm{Pb}, \mathrm{Cu}, \mathrm{Ni}$ and $\mathrm{Zn}$ in sewage sludge from municipal and industrial wastewater treatment plants. Journal Hazard Mater. 2015; 119 (1-3): 245-249.

11. Derzhavni Sanitarni Pravyla i Normy zakhystu naselenykh mists vid zabrudnennia khimichnymy i biolohichnymy rechovynamy [State Sanitary Norms and Rules about protection of the settlements in Ukraine from pollution by chemical and biological substances]. 1997: 65. (In Ukrainian).
12. Derzhavni Sanitarni Pravyla i Normy 4008: 2007. Dzherela tsentralizovanoho pytnoho vodopostachannia. Ekoloho-hihiienichni vymohy do yakosti vody i pravyla vidboru [ISO 4008:2007. Sources of centralized drinking water supply. Hygienic and ecological requirements to the quality of water and rules of selection]. 2012: 27. (In Ukrainian).

13. Sanytarnye pravyla y normy № 4630-88. Zashchyta poverkhnostnykh vod ot zahriaznenyia [Sanitary Rules and Norms № 4630-88. Protection of surface water from pollution]. 1989: 35. (In Russian).

Research work was carried out within a framework on the cathedral theme of the research work: "Scientific substantiation ecological and hygienic measures to prevent the negative influence of antropogenic factors on the environment and state of the population health", state registration number 0108U011276 (implementation period 2014-2018 years).

\section{ORCID and contributionship:}

Luibov V. Hryhorenko: 0000-0002-9517-5975 C, D, F

Svitlana Yu. Yehorova: 0000-0002-2456-4324 A, B, E

\section{CORRESPONDING AUTHOR Luibov V. Hryhorenko}

Dnipropetrovsk Medical Academy Ministry of Health of Ukraine 9 Volodymyra Vernadskogo St., 49044 Dnipro, Ukraine tel: +380680091847

e-mail:hryhorenkoluibov@ukr.net

Received: 10.11.2019

Accepted: 25.06 .2020

A - Work concept and design, B - Data collection and analysis, C - Responsibility for statistical analysis, D-Writing the article, E-Critical review, $\mathbf{F}$ - Final approval of the article 